\title{
INTERNATIONAL COOPERATION IN THE FIELD OF EDUCATION AS A TOOL OF SOFT POWER
}

\author{
Anna Filatova ${ }^{1^{*}}$, Galina Tsvetkova ${ }^{2}$ \\ ${ }^{1}$ Assoc. Prof. Dr., Mari State University, Russia, annvit@rambler.ru \\ ${ }^{2}$ Assoc. Prof. Dr., Mari State University, Volga State University of Technology, Russia, \\ galla_200760@mail.ru \\ ${ }^{*}$ Corresponding author
}

\begin{abstract}
Globalization and digitalization as key trends in the modern world ensure the growth of international cooperation in the field of education. The knowledge economy creates a growing demand for competitive education not only within the country but also abroad. Educational services are a growing export item, soft power that promotes not only well-known universities, but also local universities to export markets. At the same time, soft power strategy allows Russian regions to promote local brands, national culture along with educational services.
\end{abstract}

The goal of the paper is to show practical aspects of international cooperation in the field of education on the example of two local universities - Mari State University and Volga State University of Technology (the Republic of Mari El, Russia). The authors provide statistical data that confirm the growth both in the number of international students and the number of countries they come from. Currently, almost three thousand international students have come to study in the Republic of Mari El from the CIS countries, Central, South and Southeast Asia, the Middle East, Africa, South and North America.

Arriving in a foreign country, international students face various sorts of difficulties. First of all, they are directly related to the educational process, since a significant part of the classes are conducted in Russian. To make the process of learning more comfortable, teachers should adapt teaching materials for foreign students: highlight key points and give clear examples. Moreover, they should create "safe" learning environment in which students can feel confident in their abilities, give the opportunity to work at their own pace, make their speech clear and distinct.

International students have difficulties not only with educational process but also with adaptation to new living conditions. Promotion of international friendship greatly depends on how successful universities are in creating a safe educational environment for international students. Currently, growth in educational services for international students is the result of a good ratio between the price and the quality of educational services, low communication barriers for visitors from the CIS countries, a favorable environment and infrastructure.

Thus, international cooperation of the universities in the Republic of Mari El is an instrument of soft power, a tool for promoting the provincial region to overseas markets.

Keywords: international students, educational environment, methodological support, international cooperation, export

\section{INTRODUCTION}

Globalization and digitalization as key trends in the modern world ensure the growth of international cooperation in the field of education. The knowledge economy creates a growing demand for competitive education not only within the country but also abroad. It should be noted that Russian universities have 
always understood the strategic value of international cooperation in the field of education. Historical facts show that in 1865 this issue was actively discussed at the state level, lobbied. As a result, foreign students were exempted from tuition fees (Sheregi, Dmitriev and Arefyev, 2002). The geopolitical significance of the export of Russian education is indicated in many strategic documents, in particular, the federal program "Export of Education" within the national project "Education". Educational services are a growing export item, soft power that promotes not only well-known universities, but also local universities to export markets. At the same time, soft power strategy allows Russian regions to promote local brands, national culture along with educational services. In this connection, the purpose of the research is to study the practice of international cooperation in the field of education on the example of regional universities.

International cooperation in the field of education is the object of research by scientists from different fields of knowledge. One of the basic concepts that unites all studies is the triple helix concept developed by G. Itskowitz (Itskowitz, 2010). The triple helix concept shows that the development of the education sector is impossible without active cooperation between universities, business and the state. Today all three subjects of this interaction are active participants in international markets including the global market of educational services.

Representatives of political science define international cooperation in education as an instrument of soft power, knowledge diplomacy and smart diplomacy (Nye, 2004).

Research into institutional factors of international cooperation (Mazzarol, Soutar, 2002; Melikyan, 2017) has influenced the understanding of the object of the study. The comparative analysis of international academic cooperation between Germany and Russia (Yushkova, Neborskaya, 2016), a comparative analysis of educational space functioning within the Bologna process, CIS, SCO and EurAsEC (Voevoda, 2015) present interest for researchers.

Economists position Russian education as a strategic export item, as a non-resource export (Shtykhno, 2018). Studies that define the export of educational services as a factor of the development of the Russian regions are singled out.

\section{RESEARCH AND RESULTS}

International cooperation of Russian universities in the field of higher education is based on the regulatory framework which consists of international and federal documents. First of all, these are the provisions of the Bologna Declaration of 1999, aimed at the development of international cooperation by stimulating academic mobility of students and teachers, the development of joint educational programs, the creation of a European system of transferable credits.

Federal Law of the Russian Federation No. 273-FZ of 29.12 .2012 (as amended on 02.07.2021) "On Education in the Russian Federation" considers the following forms and directions of international cooperation in the field of education:

1) Development and implementation of joint educational, scientific programs with international or foreign organizations;

2) Sending students, teachers and researchers to foreign educational organizations with the opportunity to get special scholarships to study abroad;

3) Admission of foreign students, teachers and researchers to Russian educational organizations for the purpose of training, professional development and improvement of scientific and educational activities, including international academic exchange;

4) Conducting joint scientific research, carrying out fundamental and applied scientific research in the field of education, joint implementation of innovative activities;

5) Participation in the online form of the implementation of educational programs;

6) Participation in the activities of international organizations and the conduct of international educational, research, scientific and technical projects, congresses, symposiums, conferences, seminars or independent conduct of these events;

7) Exchange of educational and scientific literature on a bilateral and multilateral basis.

According to Russian legislation, international cooperation in the field of education is considered as a "soft power", since it involves the creation of partnerships, network forms of interaction between domestic and foreign universities which are soft methods of achieving goals. 
Among the key documents of the Russian Federation, we will name "The Concept of the export of educational services of the Russian Federation for the period 2011-2020". Most experts note the important role of the state in the development of the export of Russian education as an institution that creates favorable conditions for its development at the national (the system of support and development of the export of Russian education) and interstate (cooperation with foreign countries, participation in regional integration associations, international organizations and forums) levels. (Krasnova, 2020).

Main institutional factors that shape the peculiarities of the export of services of Russian universities are the following: domestic legislation regarding the education of foreign citizens, the rules for their stay on the Russian territory; the possibility of obtaining state financial support by a foreign student, the possibility of combining educational and labor processes; recognition of Russian diplomas in foreign countries; the cost of studying and living in Russia; the security of being in the country (Mazzarol, Soutar, 2002).

The growth in the number of foreign students studying in Russia indicates the positive dynamics of international cooperation (Figure 1). A slight decrease in the number of foreign students in 2019/2020 from the CIS countries, the Baltic States, Abkhazia and South Ossetia is primarily due to the Covid-19 factor (Minaeva, 2020).

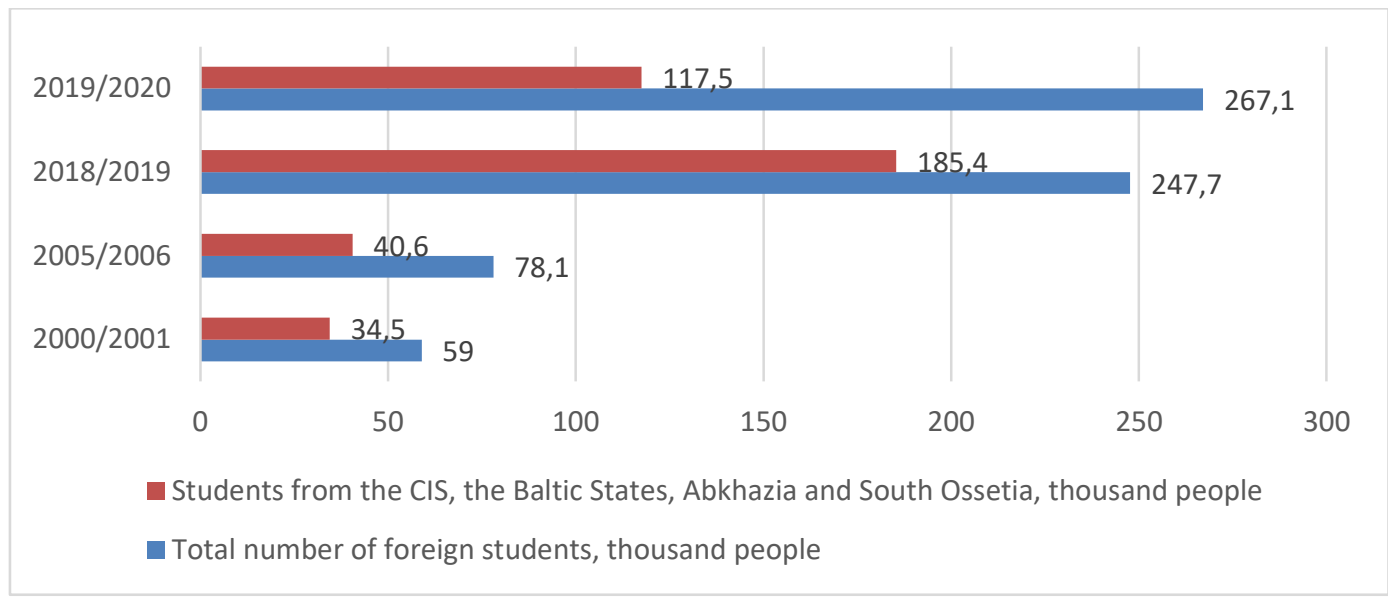

Fig. 1. The number of foreign students enrolled in bachelor's, specialist's, master's programs (at the beginning of the academic year).

Based on the data: https://rosstat.gov.ru/storage/mediabank/GOyirKPV/Rus 2020.pdf

A critical analysis of the scientific literature allows us to present a list of the main strategies of international cooperation of Russian universities in the field of higher education:

1. Strategy of a coordinated approach;

2. Strategy of supporting the migration of leading foreign specialists and gifted students;

3. Income strategy;

4. Strategy of expanded opportunities;

5. Strategy to improve the global image of the university;

6. Strategy of helping students to achieve an understanding of other cultures and acquire an international outlook;

7. Strategy of acquiring professional competencies (Khalova, 2018).

Each of these strategies considers its own technologies and forms of organization of international cooperation as a priority. For example, the strategy of a coordinated approach relies on long-term international cooperation, provides for funding from grants. The second strategy contributes to improving the quality of education. The income strategy gives preference to the commercial component, provides for the provision of higher education on a fee-paying basis. The strategy of expanded opportunities is based on the possibility of teaching foreign and Russian students in double degree programs. The strategy to improve the global image of the university focuses Russian universities on increasing their competitive positions in the world rankings. The implementation of the strategy of helping students to achieve an understanding of other cultures and acquire an international outlook is based on creating a favorable environment in the educational 
space of the university. The strategy of acquiring professional competencies provides international students with competitiveness in the international labor market. The authors support the point of view of the Rector of MGIMO University (Moscow State Institute of International Relations) A. Torkunov who believes that Russian universities should maintain and improve the quality of foreign student training, maintain the financial stability of universities giving preference to any strategy of international cooperation (Torkunov, 2017).

The practical aspects of international cooperation in the field of education are considered by the authors on the example of two universities of the Republic of Mari El: Mari State University (MARGU) and Volga State University of Technology (PGTU). Currently, almost three thousand foreign students have come to study in the Republic of Mari El from the CIS countries, Central, South and Southeast Asia, the Middle East, Africa, South and North America.

Monitoring of Russia's University Performance has been applied since 2012, one of its indicators is international cooperation in the field of education (Table 1).

Table 1. Indicators for monitoring the performance of the universities in the Republic of Mari El in international cooperation, 2020

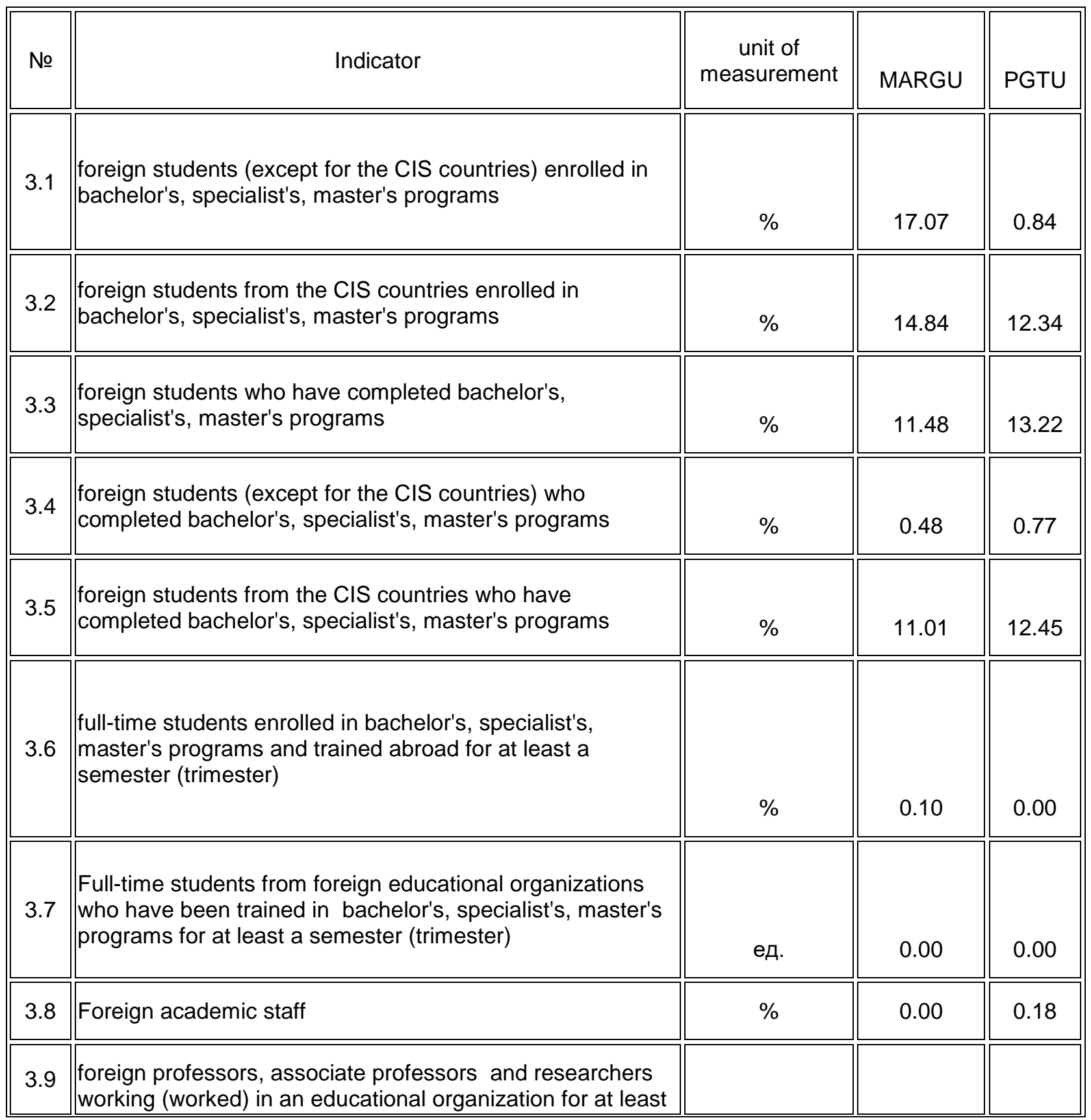




\begin{tabular}{|c|c|c|c|c|}
\hline & 1 semester & person & 0 & 0 \\
\hline 3.10 & $\begin{array}{l}\text { foreign (except for the CIS countries) postgraduates } \\
\text { (adjuncts), residents, assistant lecturers }\end{array}$ & $\%$ & 1.31 & 2.97 \\
\hline 3.11 & $\begin{array}{l}\text { foreign (from the CIS countries) postgraduates (adjuncts), } \\
\text { residents, assistant lecturers }\end{array}$ & $\%$ & 2.61 & 1.98 \\
\hline 3.12 & $\begin{array}{l}\text { The amount of finance from R\&D carried out by foreign } \\
\text { citizens and foreign legal entities }\end{array}$ & $\begin{array}{l}\text { thousand } \\
\text { roubles }\end{array}$ & 6694.00 & $\begin{array}{c}4 \\
653.10\end{array}$ \\
\hline 3.13 & $\begin{array}{l}\text { The amount of finance from educational activities performed } \\
\text { by foreign citizens and foreign legal entities }\end{array}$ & $\begin{array}{l}\text { thousand } \\
\text { roubles }\end{array}$ & 238322.20 & $\begin{array}{c}15 \\
285.80\end{array}$ \\
\hline
\end{tabular}

Based on the data: https://monitoring.miccedu.ru/iam/2021/_vpo/inst.php?id=123

It is necessary to pay attention to the geography of foreign students which is not much different from the allRussian one. A significant part of foreign students are from the CIS countries. In $2020,14.84 \%$ of the total number of students at Mari State University was foreign students from the CIS, the number of foreign students from the CIS at Volga State University of Technology was $12.34 \%$. The number of foreign students (except from the CIS countries) at Mari State University was $17.07 \%$. A significant part of these students have come to study from India to get a degree in medicine. Today, Mari State University implements two educational programs in English - in medicine and pharmacy.

The financial side of the export of educational services is reflected in Monitoring Indicators 3.12 and 3.13. Mari State University has better financial results, in particular, the amount of finance from R\&D carried out by foreign citizens and foreign legal entities was 6,694,00 thousand rubles.

In general, the universities of the Republic of Mari El conduct active marketing campaigns to promote universities and educational programs to foreign markets. Both universities have English-language versions of websites that contain up-to-date information, are easy to use and have a modern design that helps build effective intercultural communication with foreign partners. PGTU has more than 50 agreements with foreign and international organizations in the field of education and science. Mari State University has concluded about thirty agreements in the field of education and science with universities in the CIS countries, Asia, Europe and the USA.

There are special departments in each university, the purpose of which is to promote the internationalization of the educational environment of universities, their integration into the world educational space.

The departments complete the following tasks:

- Recruitment of international students;

- Regulatory and legal support for the education of international students at the university and their stay on the territory of the Russian Federation;

- Assistance in the social and cultural adaptation of international students to the conditions of study and living in Russia, popularization of the Russian language and Russian culture;

- Promotion of the university's educational programs to the international market;

- Coordination of the development and implementation of joint educational programs with Russian and foreign universities.

However, there are some facts that prevent international students from studying in Russia:

1) Poor knowledge of the Russian language; 
2) Lack of a strategic vision of the prospects of studying abroad, insufficient motivation;

3) Lack of time to master the bachelor's degree program.

Arriving in a foreign country, international students face various sorts of difficulties. First of all, they are directly related to the educational process, since a significant part of the classes are conducted in Russian. To make learning process more comfortable, teachers should adapt teaching materials for foreign students: highlight key points and give clear examples. Moreover, they should create "safe" learning environment in which students can feel confident in their abilities, give the opportunity to work at their own pace, make their speech clear and distinct.

International students have difficulties not only with educational process but also with adaptation to new living conditions. Promotion of international friendship greatly depends on how successful universities are in creating a safe educational environment for international students. Currently, growth in educational services for international students is the result of a good ratio between the price and the quality of educational services, low communication barriers for visitors from the CIS countries, a favorable environment and infrastructure.

\section{CONCLUSIONS}

Currently, the efforts of practitioners, experts and the university community are aimed at finding effective models for exporting Russian education. To make international cooperation of Russian universities in education a driver of social and economic development, it is necessary to improve organizational, legal, informational and financial mechanisms.

International cooperation of universities of the Republic of Mari El is a tool of soft power, a tool for promoting a provincial region to foreign markets. Universities are focused on creating new educational products that meet the needs of foreign partners. Like other Russian universities, the universities in the Mari El Republic should develop new forms of joint educational programs, programs in English, develop online education for foreign citizens, develop new educational tourist routes, summer training programs for foreign citizens within the framework of the national project "Export of Education".

\section{REFERENCE LIST}

Itskovits, G. (2010). Triple helix. Universities, enterprises, the state. Innovation in action. Tomsk: Publishing House of the State University of Control Systems and Radio Electronics. $107 \mathrm{p}$.

Khakhalova, S.A. (2018). Internationalization of medical education in Russia. Online magazine "World of Science", 6. https://mir-nauki.com/PDF/02PDMN618.pdf

Krasnova, G.A. (2020). Model of export support of Russian education. Public Service, 2. pp. 107-118.

Mazzarol, T., Soutar, G. (2002). Push-Pull Factors Influencing International Student Destination Choice. The International Journal of Educational Management, 16 (2). pp. 82-90.

Minaeva, E.A. (2020). Changes in the work of universities to attract foreign students during the pandemic. Information and analytical materials based on the results of statistical and sociological surveys. Monitoring of the economics of education, 24. pp.1-7. https://www.hse.ru/data/2020/10/19/

Nye, J. (2004). "Soft power" and US-European relations. Free Thought-XXI, 10. http://smartpowerjournal.ru/soft-power

Sheregi, F.E., Dmitriev, N.M. and Arefyev, A.L. (2002). Scientific and pedagogical potential and export of educational services of Russian universities (sociological analysis). Moscow: Center for Social Forecasting. $552 \mathrm{p}$.

Shtykhno, D. (2018). Export of education as a potential factor in the development of the regions of the Russian Federation. Federalism, 4. pp. 195-203.

The Bologna Declaration (2005). European Higher Education Area: Joint Statement of the European Ministers of Education signed in Bologna on July 19, 1999. Bulletin of the Russian Philosophical Society, 1 (33). pp. 74-77. 
The concept of export of educational services of the Russian Federation for the period $2011-2020$. (2010). Bulletin of International Organizations, 1(27). pp. 96-106.

Torkunov, A. (2017). Russian universities in the process of internationalization challenges and priorities. International Processes, 15(1). pp. 6-12.

Voevoda, E. (2015). Communication barriers of the BRICS educational space. International processes, 13 (4). pp. 108-121.

Yushkova, L.A., Neborskaya, V.V. (2016). International cooperation in the field of higher education (on the example of Russian and German universities). Online magazine "World of Science", 4(4). http://mirnauki.com/PDF/33PDMN416.pdf 